\title{
Practices suggested in social media for birth plans
}

\author{
Práticas sugeridas em mídias sociais para planos de parto \\ Prácticas sugeridas en las redes sociales sobre la planificación de los partos
}

'Pontifícia Universidade Católica do Rio Grande do Sul, Hospital

São Lucas. Porto Alegre, Rio Grande do Sul, Brazil.

"Universidade Federal do Rio Grande do Sul. Porto Alegre,

Rio Grande do Sul, Brazil.

How to cite this article:

Pasqualotto VP, Riffel MJ, Moretto VL. Suggested

social media practices for birth plans.

Rev Bras Enferm. 2020;73(5):e20180847.

doi: http://dx.doi.org/10.1590/0034-7167-2018-0847

Corresponding author:

Mariene Jaeger Riffel

E-mail: marieneriffel@gmail.com

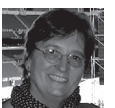

EDITOR IN CHIEF: Antonio José de Almeira Filho ASSOCIATE EDITOR: Fátima Helena Espírito Santo

Submission: $08-03-2018$

Approval: 09-24-2019

\begin{abstract}
Objective: To describe and analyze the practices suggested in social media for the elaboration of Birth Plans, available on Blogs/Sites and not included in the WHO recommendations. Method: Qualitative, exploratory, descriptive study with thematic analysis. A total of 41 e-mail addresses were selected for analysis among the 200 web addresses previously identified between March and July 2016. Three web addresses were in Portugal and the others in Brazil. Results: 48 practices not included in the recommendations of the World Health Organization (WHO) were identified. Conclusion: Blogs/Websites, as means of transmission, circulation and production of knowledge, enable the horizontal expression of values, encourage women to plan the events considered important for their deliveries and put childbirth decisions on the hands of women, which has caused controversy in the discourse of humanization of childbirth. Descriptors: Humanizing Delivery; Obstetric Nursing; Evidence-Based Nursing; Health Education; Social Media.
\end{abstract}

\section{RESUMO}

Objetivo: Descrever e analisar práticas sugeridas nas mídias sociais para elaboração de Planos de Partos disponíveis em Blogs/Sites e que não constam nas recomendações da OMS. Método: Estudo qualitativo, exploratório, descritivo, de análise temática. Foram selecionados para análise 41 endereços eletrônicos dos 200 previamente identificados, entre março e julho de 2016. Três endereços eletrônicos estavam sitiados em Portugal e os demais no Brasil. Resultados: Foram identificadas 48 práticas não citadas entre as recomendações da Organização Mundial da Saúde (OMS). Conclusões: Os Blogs/Sites, por serem ferramentas de transmissão, circulação e produção de conhecimentos, possibilitam a expressão de valores de forma horizontal, instigando mulheres ao planejamento dos eventos considerados importantes para seus partos e deslocando as decisões das práticas de parto para si, o que tem provocado polêmica no discurso da humanização do parto.

Descritores: Parto Humanizado; Enfermagem Obstétrica; Enfermagem Baseada em Evidências; Educação em Saúde; Mídias Sociais.

\section{RESUMEN}

Objetivo. Describir y analizar las prácticas sugeridas en las redes sociales como Blogs/Sitios, no recomendadas por la OMS, sobre la planificación de los partos. Método. Se trata de un estudio cualitativo, exploratorio y descriptivo, de análisis temático. Entre marzo y julio de 2016, se seleccionaron 41 direcciones electrónicas de 200 identificadas con antelación. Tres estaban situadas en Portugal y las demás, en Brasil. Resultados. Se identificaron 48 prácticas no citadas entre las recomendaciones de la Organización Mundial de la Salud (OMS). Conclusión. Los Blogs/Sitios, al ser vehículos de transmisión, circulación y producción de conocimientos, permiten la expresión de valores de manera horizontal, instigando a las mujeres a planificar eventos considerados importantes para sus partos y a transferir las decisiones de las prácticas del parto para sí, lo que ha generado controversia en el discurso de la humanización del trabajo de parto.

Descriptores: Parto Humanizado; Enfermería Obstétrica; Enfermería Basada en Evidencias; Educación en Salud; Redes Sociales. 


\section{INTRODUCTION}

Every birth is a unique process in women's lives and each event brings different meanings. Predicting a growing trend of interventions, the WHO has encouraged countries to reassess the technologies used in childbirth and has drawn up a list of practices ${ }^{(1)}$ that has encouraged women to choose the type of birth they want ${ }^{(2)}$.

Expectations of pregnant women regarding the type of delivery have been related to how the information on the subject is made available and how easily they can access this information.

The Birth Plan is a favorable strategy for sharing and discussing good quality information during prenatal care $^{(2-3)}$. It is also the first practice listed according to level of evidence in the set of activities classified by the $\mathrm{WHO}^{(1)}$ in 1996. In 2018, the $\mathrm{WHO}^{(4)}$ classified practices for intrapartum care according to the stages of labor.

If in 1996 it was recommended that the Birth Plan should be designed as "a personal plan determining where and by whom birth will be attended, made with the woman during pregnancy and made known to her husband/partner and, if applicable, to the family"(1:3), in 2018 it is described as a document that must be individualized "according to the woman's needs and preferences". Therefore, the Birth Plan should be elaborated by the pregnant woman, based on information provided by the professionals who provide prenatal care according to the best available evidence $\mathrm{e}^{(2-4)}$.

The publication of the WHO Plan of Birth Recommendations ${ }^{(1)}$ occurred at the time of the emergence of the World Wide Web -WWW. The web (or internet) provides a large volume of information that can quickly and globally put women in touch with their interests and needs ${ }^{(5)}$. Social media generates new political perspectives shared between individuals, in civil society and in the local and municipal governments, and also offers possibilities to understand the challenges of building democratic citizenship in contemporary times ${ }^{(6)}$. Blogs/Websites, as social environments, are important in Health Education regarding childbirth and, therefore, are relevant for user and professional autonomy.

The importance of the Birth Plan may be related to the prevention of obstetric violence, which is defined as acts performed by health professionals to the female body during reproductive processes characterized by overuse of interventions, unnecessary medication, pathologization of the normal physiological processes of birth, and negligence ${ }^{(7)}$. The Birth Plan is focused on respecting women's choices regarding their own childbirth and on the right to dignified, respectful care, without any kind of violence ${ }^{(1,4)}$.

The evidence used in the elaboration of a Birth Plan is constantly updated according to new studies, which currently indicate that practices can be less interventionist, more respectful and dignified, and still maintain or improve perinatal outcomes ${ }^{(3)}$. The elaboration of a Birth Plan must be based on new attitudes and perspectives regarding dominant practices: changing a practice means that one has had the opportunity to rethink and has the strength to make changes occur.

Believing that Blogs/Sites are places of transmission, circulation and production of knowledge that give voice to women, the following guiding questions were elaborated: Do Blogs/Websites suggest practices different from those recommended by WHO for Birth Plans? What are the practices suggested?

\section{OBJECTIVE}

To describe and analyze the practices suggested in social media for the elaboration of Birth Plans, available on Blogs/Sites and not included in the WHO recommendations ${ }^{(1,4)}$.

\section{METHODS}

\section{Ethical aspects}

The description of the analysis and discussion respected ethical aspects related to the authorship of the texts studied and the checklist of the Consolidated Criteria for Reporting Qualitative Studies (COREQ). As the data analyzed had a public and unrestricted character, the project that originated this study was not submitted to the Research Ethics Committee, as it is not included in the CEP-CONEP specifications.

\section{Study design, setting, data sources}

This is a qualitative, exploratory, descriptive study ${ }^{(8)}$.

The Google website was chosen to search for analysis material, as it is considered "the largest source of visitors for the vast majority of Blogs"(5). It is the first page of results and it receives the highest number of visits ${ }^{(9)}$ on the web.

The data sources were Blogs/Websites that contained suggestions for Birth Plans.

\section{Inclusion and exclusion criteria, data organization and period}

The terms WHO, PDF and SUS were chosen to go along with"Birth Plan" when searching for publications of interest for the study. A total of 200 web addresses were selected on March 31, 2016. Between April and July, 41 web addresses were identified, 26 blogs and 15 websites, three in Portugal and the others in Brazil. The determination of these 41 web addresses occurred by crossing information, which showed that 56 addresses were repeated and 103 did not have suggestions for Birth Plans or this information could not be accessed.

Chart 1 - List of Blogs/Websites, year of publication and web addresses selected

\begin{tabular}{|c|c|c|}
\hline $\begin{array}{l}\text { Name of the } \\
\text { blog/wesite }\end{array}$ & Year & Web address \\
\hline Pais e filhos & \multirow{2}{*}{2009} & $\begin{array}{l}\text { http://www.paisefilhos.pt/index.php/gravidez/ } \\
\text { parto/1012-exemplo-de-um-plano-de-parto }\end{array}$ \\
\hline Materna Japão & & $\begin{array}{l}\text { http://maternajapao.blogspot.com.br/2009/04/ } \\
\text { como-fazer-um-plano-de-parto.html }\end{array}$ \\
\hline $\begin{array}{l}\text { De mãe para } \\
\text { mãe }\end{array}$ & 2011 & $\begin{array}{l}\text { http://demaeparamae.pt/sites/default/files/ } \\
\text { forum/90525/plano_de_parto_3.pdf }\end{array}$ \\
\hline Vila Mamífera 2 & \multirow{3}{*}{2013} & http:// vilamamifera.com/dadada/334/ \\
\hline Sites Uai & & $\begin{array}{l}\text { http://www.uai.com.br/app/noticia/ } \\
\text { saude/2013/10/28/noticias-saude,193593/ }\end{array}$ \\
\hline Vida Materna & & $\begin{array}{l}\text { http://www.vidamaterna.com/escrevendo-um- } \\
\text { plano-de-parto-e-como-eu-escrevi-o-meu/ }\end{array}$ \\
\hline
\end{tabular}

To be continued 
Chart 1

\begin{tabular}{|c|c|c|}
\hline $\begin{array}{l}\text { Name of the } \\
\text { blog/wesite }\end{array}$ & Year & Web address \\
\hline Mãezíssima & \multirow{3}{*}{2013} & $\begin{array}{l}\text { http://www.maezissima.com.br/criar-e- } \\
\text { educar/plano-de-parto/ }\end{array}$ \\
\hline $\begin{array}{c}\text { Vida de } \\
\text { gestante e mãe }\end{array}$ & & $\begin{array}{l}\text { http://www.vidadegestanteemae.com.br/wp- } \\
\text { content/uploads/2013/11/PLANO-DE-PARTO.pdf }\end{array}$ \\
\hline $\begin{array}{l}\text { Cartilha da } \\
\text { Gestante }\end{array}$ & & $\begin{array}{l}\text { http://portalpbh.pbh.gov.br/pbh/ecp/files. } \\
\text { do?evento=download\&urlArqPIc=cartil } \\
\text { ha_gestante_2013_web.pdf }\end{array}$ \\
\hline Vila Mamífera 1 & \multirow{9}{*}{2014} & $\begin{array}{l}\text { http://vilamamifera.com/ } \\
\text { mulheresempoderadas/plano-de-parto-2/ }\end{array}$ \\
\hline $\begin{array}{l}\text { Núcleo bem } \\
\text { nascer }\end{array}$ & & $\begin{array}{l}\text { http://www.nucleobemnascer.com/sites/ } \\
\text { default/files/files/plano_de_parto.pdf }\end{array}$ \\
\hline $\begin{array}{l}\text { Violência } \\
\text { Obstétrica }\end{array}$ & & $\begin{array}{l}\text { http://violenciaobstetricasc.blogspot.com. } \\
\text { br/2014/12/plano-de-parto-o-que-e-como- } \\
\text { protocolar.html }\end{array}$ \\
\hline $\begin{array}{l}\text { E agora } \\
\text { gestante }\end{array}$ & & $\begin{array}{l}\text { https://eagoragestante.wordpress. } \\
\text { com/2014/06/26/plano-de-parto-o-que-e-e- } \\
\text { importante-como-fazer/ }\end{array}$ \\
\hline $\begin{array}{l}\text { Waldorf em } \\
\text { casa }\end{array}$ & & $\begin{array}{l}\text { http://waldorfemcasa.blogspot.com. } \\
\text { br/2014/11/plano-de-parto-comentado.html }\end{array}$ \\
\hline Pequenininho & & $\begin{array}{l}\text { http://www.pequenininho.com/2014/04/ } \\
\text { plano-de-parto-francisco.html }\end{array}$ \\
\hline $\begin{array}{l}\text { Me sinto } \\
\text { grávida }\end{array}$ & & $\begin{array}{l}\text { http://www.mesintogravida.com.br/2014/04/ } \\
\text { plano-de-parto-do-artur/ }\end{array}$ \\
\hline Rede mãe & & http://redemae.com.br/plano-de-parto/12546 \\
\hline Instituto Nascer & & $\begin{array}{l}\text { http://institutonascer.com.br/como-escrever- } \\
\text { seu-plano-de-parto/ }\end{array}$ \\
\hline M de Mulher & \multirow{5}{*}{2015} & $\begin{array}{l}\text { http://m.mdemulher.abril.com.br/saude/bebe/ } \\
\text { entenda-como-funciona-o-plano-de-parto }\end{array}$ \\
\hline Mães de peito & & $\begin{array}{l}\text { http://www.maesdepeito.com.br/saiba-a- } \\
\text { importancia-do-plano-de-parto-e-como- } \\
\text { fazer-o-seu/ }\end{array}$ \\
\hline Dr. Lu Herrero & & $\begin{array}{l}\text { http://www.dralucianaherrero.com.br/plano- } \\
\text { de-parto-normal/ }\end{array}$ \\
\hline Rebeca Doula & & $\begin{array}{l}\text { http://rebeca-doula.blogspot.com.br/p/plano- } \\
\text { de-parto.html }\end{array}$ \\
\hline $\begin{array}{l}\text { Recanto da } \\
\text { mamãe }\end{array}$ & & $\begin{array}{l}\text { http://www.recantodamamae.com.br/saude/ } \\
\text { plano-de-parto/ }\end{array}$ \\
\hline Bebe em casa & \multirow{4}{*}{2015} & $\begin{array}{l}\text { http://www.bebemcasa.com.br/2015/04/ } \\
\text { plano-de-parto.html }\end{array}$ \\
\hline $\begin{array}{l}\text { Sentidos do } \\
\text { Nascer }\end{array}$ & & $\begin{array}{l}\text { http://www.sentidosdonascer.org/wordpress/ } \\
\text { wp-content/themes/sentidos-do-nascer/ } \\
\text { assets/pdf/Planodeparto.pdf }\end{array}$ \\
\hline $\begin{array}{l}\text { Associação } \\
\text { Portuguesa }\end{array}$ & & $\begin{array}{l}\text { http://www.associacaogravidezeparto.pt/ } \\
\text { wp-content/uploads/2015/02/Plano-de-Parto- } \\
\text { APDMGP.pdf }\end{array}$ \\
\hline Roseli Nomura & & $\begin{array}{l}\text { http://www.cremesp.org.br/pdfs/eventos/ } \\
\text { eve_11112015_082203_Plano\%20de\%20 } \\
\text { Parto\%20e\%20Parto\%20Humanizado } \\
\text { Dra.\%20Roseli\%20Mieko\%20Yamamoto\%20 } \\
\text { Nomura\%20(4)\%20(1).pdf }\end{array}$ \\
\hline Sim senhora & 2016 & $\begin{array}{l}\text { http://www.simsenhora.com/2016/03/meu- } \\
\text { plano-de-parto.html }\end{array}$ \\
\hline
\end{tabular}

\begin{tabular}{|c|c|c|}
\hline $\begin{array}{l}\text { Name of the } \\
\text { blog/wesite }\end{array}$ & Year & Web address \\
\hline $\begin{array}{l}\text { Grávidas } \\
\text { antenadas }\end{array}$ & \multirow{3}{*}{2016} & $\begin{array}{l}\text { http://www.gravidaseantenadas.com. } \\
\text { br/2016/02/11/o-que-e-um-plano-de-parto/ }\end{array}$ \\
\hline Porto Materno & & $\begin{array}{l}\text { https://portomaterno.com/check-list/plano- } \\
\text { de-parto/ }\end{array}$ \\
\hline Comparto & & $\begin{array}{l}\text { http://comparto.com.br/wp-content/ } \\
\text { uploads/2016/01/planodeparto.pdf }\end{array}$ \\
\hline $\begin{array}{l}\text { Amigas do } \\
\text { parto }\end{array}$ & \multirow{10}{*}{ n.d. } & $\begin{array}{l}\text { http://www.amigasdoparto.com.br/plano3. } \\
\text { html }\end{array}$ \\
\hline Engravidar & & http://www.engravidar.blog.br/plano-de-parto/ \\
\hline Bebe mamãe & & $\begin{array}{l}\text { http://bebemamae.com/parto/plano-de- } \\
\text { parto-o-que-e-e-como-realizar }\end{array}$ \\
\hline $\begin{array}{l}\text { Espaço Parto } \\
\text { Adequado }\end{array}$ & & $\begin{array}{l}\text { http://espacopartoadequado.e-vida.org.br/ } \\
\text { noticia/O-que-e-plano-de-parto }\end{array}$ \\
\hline $\begin{array}{l}\text { Despertar do } \\
\text { parto }\end{array}$ & & $\begin{array}{l}\text { http://www.despertardoparto.com.br/ } \\
\text { modelo-de-plano-de-parto.html }\end{array}$ \\
\hline $\begin{array}{l}\text { Bolsa de } \\
\text { Mulher }\end{array}$ & & $\begin{array}{l}\text { http://www.vix.com/pt/bdm/bebe/8238/ } \\
\text { plano-de-parto-o-que-e-e-como-fazer-um }\end{array}$ \\
\hline Primeiros dias & & $\begin{array}{l}\text { http://www.primeirosdias.com/parto- } \\
\text { humanizado.html }\end{array}$ \\
\hline In Utero & & $\begin{array}{l}\text { http://www.inutero.pt/UserFiles/File/artigos/ } \\
\text { nascimento/Plano\%20de\%20Parto.pdf }\end{array}$ \\
\hline SAPO & & $\begin{array}{l}\text { http://lifestyle.sapo.pt/familia/gravidez/ } \\
\text { artigos/deve-fazer-um-plano-de-nascimento }\end{array}$ \\
\hline Artemis & & $\begin{array}{l}\text { http://pt.slideshare.net/Marcusrenato/plano- } \\
\text { de-parto-modelo-da-artemis-e-defensoria- } \\
\text { pblica-de-so-paulo }\end{array}$ \\
\hline
\end{tabular}

Note: $n . d .=$ no date.

The information found in the Birth Plan suggestions was typed in an Excel spreadsheet that contained the names of the 41 Blogs/ Websites in its rows. All practices identified were categorized into columns and then compared with those described in the WHO recommendations $s^{(1,4)}$.

\section{Analysis of data}

The initial analysis occurred between August and December 2016, when the practices identified were compared with those recommended by WHO up to this year. For the elaboration of this article, the analysis was reviewed according to recommendations published in $2018^{(4)}$, which showed that the categories described in the initial analysis of this study were already aligned with the current recommendations $s^{(4)}$. Therefore, the criteria for classifying the practices in this study were the periods during or before hospitalization, during labor, during delivery, in postpartum or in case of c-section. An electronic file of the material selected for analysis was constructed in the Excel program, using the program's "filter" feature, which showed 48 practices different from the recommendations published in $1996^{(1)}$ and in $2018^{(4)}$. During data analysis, Cultural Studies methods were applied, meaning that methodological choices were made in a practical and reflective manner, according to the demands posed by the research problem, 
which does not represent lack of scientific rigor ${ }^{(10)}$. The analysis of the material published by WHO in comparison with the empirical material produced in cyberspace, enhanced both sources, without one excluding the other. Immersion into cyberculture produced in a cyberspace showed ways of producing practices that go beyond those described by $\mathrm{WHO}$, releasing specific, important and necessary practices and knowledge, described by internet users, into the space of science and society.

\section{RESULTS}

Forty-one Birth Plans were analyzed, from which 48 practices not included in the WHO recommendations emerged ${ }^{(1,4)}$, as shown in Chart 2.

Chart 2 - Practices not included in the World Health Organization classification

\begin{tabular}{|c|c|c|}
\hline Períodos & Práticas sugeridas nas mídias socias & FR \\
\hline \multirow{5}{*}{$\begin{array}{l}\text { Antes/ } \\
\text { durante a } \\
\text { internação }\end{array}$} & Utilização de objetos pessoais & 13 \\
\hline & Ser chamada pelo nome & 4 \\
\hline & Opção de utilização do serviço público ou privado & 2 \\
\hline & $\begin{array}{l}\text { Possibilidade de interrupção da gestação a termo } \\
\text { ou após }\end{array}$ & 2 \\
\hline & Manutenção do celular & 1 \\
\hline \multirow{6}{*}{$\begin{array}{l}\text { Durante o } \\
\text { trabalho } \\
\text { de parto }\end{array}$} & $\begin{array}{l}\text { Acompanhante de parto profissional (massagista, } \\
\text { doula, fisioterapeuta...) sem vínculo com o hospital }\end{array}$ & 26 \\
\hline & Ouvir música durante o trabalho de parto & 21 \\
\hline & Aguardar trabalho de parto ativo no domicílio & 5 \\
\hline & Silêncio durante & 4 \\
\hline & Decisão sobre quando avisar a família & 1 \\
\hline & $\begin{array}{l}\text { Ausculta de Batimentos Cárdio Fetais e toque vaginal } \\
\text { realizados pela Enfermeira Obstétrica e não pela } \\
\text { equipe do hospital }\end{array}$ & 1 \\
\hline \multirow{10}{*}{$\begin{array}{l}\text { Durante o } \\
\text { parto }\end{array}$} & Penumbra ao nascimento & 31 \\
\hline & Corte do cordão umbilical pelo pai após parto & 23 \\
\hline & Fotografar/filmar & 12 \\
\hline & Visualização da placenta logo após dequitação & 11 \\
\hline & Tocar a cabeça do bebê no coroamento & 10 \\
\hline & Ver o nascimento por um espelho & 8 \\
\hline & Sem contenção de braços/pernas & 6 \\
\hline & Manutenção de estudantes no parto & 4 \\
\hline & Anestesia local para sutura de laceração & 3 \\
\hline & Não usar estribos/perneiras & 2 \\
\hline \multirow{7}{*}{$\begin{array}{l}\text { Durante o } \\
\text { parto }\end{array}$} & Coletar sangue para banco de cordão & 2 \\
\hline & $\begin{array}{l}\text { Acompanhamento do parto por profissionais de } \\
\text { sua confiança }\end{array}$ & 1 \\
\hline & Sutura de períneo mesmo se laceração pequena & 1 \\
\hline & Cordão umbilical cortado somente após a dequitação & 1 \\
\hline & $\begin{array}{l}\text { Contato pele a pele imediato e sem limpeza da } \\
\text { pele do bebê antes de entregar à mãe }\end{array}$ & 1 \\
\hline & Antissepsia dos genitais & 1 \\
\hline & Fluxo reduzido de pessoal no parto & 1 \\
\hline
\end{tabular}

\begin{tabular}{|c|c|c|}
\hline Períodos & Práticas sugeridas nas mídias socias & $\mathbf{F R}$ \\
\hline \multirow{12}{*}{ Pós parto } & Não oferecer água, fórmula, chupeta ou bico ao bebê & 30 \\
\hline & Avaliação do Recém-Nascido com mãe ou pai do bebê & 27 \\
\hline & Pessoas autorizadas a trocar ou dar banho no bebê & 16 \\
\hline & Amamentação em livre demanda & 15 \\
\hline & Postergar o banho do bebê & 14 \\
\hline & Alta hospitalar precoce & 12 \\
\hline & Opção de berçário & 6 \\
\hline & Visitação dos irmãos & 3 \\
\hline & Não vacinar bebê & 3 \\
\hline & Opção de visita de familiares ilimitada ou com restrição & 3 \\
\hline & Opção de não amamentar & 1 \\
\hline & Auxílio na amamentação & 1 \\
\hline \multirow{8}{*}{$\begin{array}{l}\text { Em caso } \\
\text { de cesárea }\end{array}$} & Mãos livres & 25 \\
\hline & Rebaixamento do protetor ou uso de espelhos & 21 \\
\hline & Escolha do tipo de anestesia para a cesárea & 16 \\
\hline & Permitir o início do trabalho de parto antes da cesárea & 15 \\
\hline & Não uso de sedativos pós-operatórios & 15 \\
\hline & RN em contato pele a pele durante sutura & 13 \\
\hline & Tricotomia parcial & 2 \\
\hline & $\begin{array}{l}\text { Escolha de médico, anestesista e hospital "amigo } \\
\text { da mulher" }\end{array}$ & 2 \\
\hline
\end{tabular}

\section{DISCUSSION}

For better understanding and analysis, the practices suggested in the Blogs/Websites were categorized according to labor stage and the updated $\mathrm{WHO}$ classification ${ }^{(4)}$ into five categories.

\section{Suggested practices before and during hospitalization for delivery}

The suggestions for this period refer mainly to the preservation of individuality and of sensory function. Regarding the use of personal objects, the suggestions included not removing contact lenses or glasses, hearing aids and dental prostheses, as it would restrict sight and hearing, or compromise the self-image of parturients. Another suggestion was the permission to wear personal clothing and to use alternative methods of pain relief and childbirth comfort, such as body-support ropes, birthing ball, seed bags, swimming pool, and yoga mats. All of these practices are recommended in the National Guidelines on Care in Normal Birth ${ }^{(11)}$. It is known that some institutions routinely deprive parturients of these objects and practices, justifying this attitude by claiming increased risk of infections or loss of objects. Current scientific evidence does not associate infections to the use of the personal objects ${ }^{(11)}$. Also, in services with organized work processes, the loss of the user's belongings is minimal or does not occur.

The Blogs/Sites emphasize that care should be individualized; therefore, women should be called by their names, and practices such as asking pregnant women to "spread their legs"(12) without knowing their names, and professionals not identifying themselves 
when examining women should be avoided. The Brazilian Civil Code $^{(13)}$ emphasizes that a person's name is a right, since it is what characterizes them in their family and in society. In addition, bonding and empathy practices reduce the possibility of violence, facilitate care and improve care outcomes ${ }^{(11)}$.

Regarding the place of choice for delivery, WHO recommends that "women should give birth in a place where they feel safe" and that spontaneous labor should be awaited ${ }^{(1)}$.

\section{Suggested practices for use during labor}

Massages, stimulation of practices such as walking, vertical positions, relaxing breathing, analgesia through electrical stimulation, promotion of and assistance in hot baths and cryotherapy contribute to the physical and emotional well-being of the pregnant woman ${ }^{(14)}$. The presence of a doula reduces c-sections, labor time, use of oxytocin, and the need for anesthesia and forceps ${ }^{(11)}$.

Pleasant sounds, absence of noises other than childbirth and/or silence facilitate the concentration of women and mobilizes archaic brain structures that help these processes to occur physiologically ${ }^{(15)}$. In this sense, music promotes the release of endorphins that make uterine contractions more bearable ${ }^{(16)}$.

Regarding the time to go to the place chosen for delivery, Blogs/ Websites alert that rush to get to the hospital opens space for a "cascade of interventions" (1). Therefore, waiting for active labor at home can prevent unnecessary practices and iatrogenesis.

Another suggestion is including in the Birth Plan the moment for communicating hospitalization and birth to family and friends, as some situations may cause embarrassment and anxiety, as described by a user of Blog/Website vila mamífera2/dadada (Chart 1): "I don't want to cause anxiety if I have long labor, but I also don't want to exclude them from the process".

\section{Suggested practices for use during childbirth: expulsion and placental stages}

Dimmed lights during delivery can promote comfort and make the environment welcoming and more similar to the mother's womb ${ }^{(15)}$.

Fathers cutting the umbilical cord is a practice that symbolizes the "beginning" of a shared responsibility for the child's development ${ }^{(17)}$. It offers no risks and may occur before or after placental expulsion ${ }^{(11)}$. The collection of umbilical cord blood for freezing depends on strict criteria, which must be clarified beforehand. The Ministry of Health and the coordination of the Brasilcord Network are opposed to the use of private cord blood banks, highlighting the lack of public benefit and the "misleading way that private cord blood banks advertising has been done. International agencies recommend no public investments in private cord blood banks"(18). Some women include seeing the placenta in their Birth Plans, and others request to take the placenta home to use it in cultural practices, causing discomfiture in maternity wards. Article 19 of the Human Rights Code advocates "freedom of opinion and expression, which includes the right to not to be disturbed"(19). Therefore, in this situation, the placenta can be delivered to the woman upon request.

There is controversy over who will capture images of the birth. Filming or photographing is a good way of remembering this moment, as long as it does not disturb the mother's concentration or prevent the father from participating in the process. For some, the decision of capturing images must be made by the birth attendant, and may"be carried out by the companion or an authorized professional, upon agreement of the physician"(20). However, we question: is it up to the birth attendant to decide whether to capture images of people who want to document part of their lives?

Seeing the birth of a child through a mirror and the possibility of touching the baby's head when crowning were suggestions to encourage women to perceive their body and their baby's movement. It is a practice with no risks and no financial costs ${ }^{(21)}$, which depends only on the sensitivity of the team It is a moment of orientation about what each push represents for the progression of the baby in the birth canal and about the modifications of the perineum. Therefore, it promotes the participation of women in the birth process. Arm and leg restraints and the use of stirrups are common practices when the lithotomy position is adopted. The research Nascer no Brasil showed that the lithotomy position is used in $91.7 \%$ of births in the country ${ }^{(22)}$. Containment practices are not encouraged or recommended, as they limit movement and skin-to-skin contact, and require woman to work against gravity during the expulsion stage ${ }^{(11)}$. Skin-to-skin contact should begin immediately after birth and continue during the "golden hour," as it soothes the baby and mother, helps the cardiorespiratory stability of the newborn, reduces crying and stress, keeps the baby warm, favors early breastfeeding and helps the formation of the microbiome ${ }^{(23)}$.

Restricting the number of people in delivery rooms provides privacy and improves outcomes of this period ${ }^{(11)}$. The inclusion of academic students in care actions qualifies teaching and care ${ }^{(24)}$, while teaching them to respect women's individuality. The presence of trusted childbirth attendants is related to the choice for public or private institutions.

Perineal laceration suture prevents postpartum hemorrhage when the tear is deep or extensive, and it should be performed under anesthesia. Most perineal lacerations are superficial and do not need suture ${ }^{(11)}$

Genital antisepsis during childbirth causes discomfort and is not associated with better outcomes. Therefore, as it does not improve infection rates, it should not be routinely performed ${ }^{(11,19)}$.

\section{Suggested practices for the postpartum period}

Current recommendations advise against the use of milk formulas, water and pacifiers, recommending exclusive breastfeeding until the sixth month of life. Breast milk contains all the nutrients and antibodies necessary for the baby ${ }^{(23)}$ and should be offered on demand. Currently, there are only few women that admit they do not want to breastfeed.

Some procedures should be delayed ${ }^{(23)}$ or not performed in the first hour of life. Thus, practices such as early cord clamping, anthropometric assessment, vaccine administration, Credé's prophylaxis, vital signs check, aspiration of the airways and gastric aspiration and lavage should be postponed. The recommendation of no bath in the first hours of life is based on the best available evidence ${ }^{(25)}$. This should not be considered carelessness; it should be seen as an important care measure. 
The presence of friends and family can bring comfort, safety and feeling of prestige and support from acquaintances ${ }^{(21)}$, even in practices such as bathing or changing the baby.

Joint accommodation is a practice recommended by the WHO so that mother and baby are not separated, as they must be together in the same room 24 hours a day ${ }^{(4)}$. Therefore, it is necessary to identify when the postpartum woman needs help to care for the newborn or when she needs rest. The nursery prevents interaction and bonding of the baby with the mother and family ${ }^{(17)}$, and hinders the promotion of care practices and health education; therefore, it is not recommended.

The suggestion of including early hospital discharge in the Birth Plan is corroborated by the $\mathrm{WHO}^{(4)}$, which recommends specialized obstetric care for at least 24 hours after an uncomplicated vaginal delivery in which mother and newborn are healthy.

In Brazil, the vaccination calendar indicates the vaccines and ages in which children should be compulsorily vaccinated ${ }^{(26)}$.

\section{Suggested practices for use before a C-Section}

Hand restrains are routinely used during C-sections to facilitate handling of equipment by anesthetists and surgeons. Since it prevents the mother from holding and breastfeeding the baby in the first hour of life and impedes skin-to-skin contact ${ }^{(25)}$, hand restraints are contrary to $\mathrm{WHO}$ recommendations ${ }^{(4)}$.

Use of mirrors and lowering curtains were the subject of professional advice on "the right of patients to dismiss hospital protocols, [because they would] cause sensitive difficulties in care, which may lead to risk of infections and other nuisances for the service provided"(27). However, monitoring birth through a mirror or by lowering curtains are more active modes of participation of women, and are not associated with increased infections ${ }^{(11)}$.

Skin-to-skin contact between mother and newborn during Csection suture is not included in the WHO recommendations ${ }^{(1,4)}$. However, skin-to-skin contact is a practice that should be stimulated and facilitated at any type of birth ${ }^{(24,27)}$.

When the woman has previously decided to have a C-section, it is important that she goes into labor. Spontaneous onset of labor decreases the chances of prematurity, increases oxytocin levels and aids in breast milk ejection ${ }^{(23)}$.
In the Brazilian Guidelines for Cesarean Operation ${ }^{(28)}$, there are no recommendations for partial shaving or any other type of hair removal.

The suggestion of including the choice of women-friendly doctors, anesthetists and hospitals ${ }^{(29)}$ in Birth Plans does not guarantee that this choice will be respected.

Sedation can lead to pregnancy amnesia and disrupt the interaction between mother and baby. Therefore, non-pharmacological pain relief strategies and methods may be associated or used exclusively, according to pain assessment after a C-section ${ }^{(30)}$.

\section{Limitations of the study}

This study had no limitations for data collection or analysis.

\section{Contributions to the area of health}

The practices and desires of women for the birth of their children, described in Birth Plans presented in Blogs/Websites and different from WHO recommendations, can broaden discussions that go in the same direction as health care models that promote critical thinking of current practices, making delivery and birth even more personalized.

\section{FINAL CONSIDERATIONS}

This research highlights the existence of an information network that encourages women to plan the events considered important for the birth of their children. Blogs/Websites, as means of transmission, circulation and production of knowledge, enable the horizontal expression of values and put childbirth decisions on the hands of women, which has caused controversy in the discourse of humanization of childbirth.

Blogs/WebSites have added 48 suggestions different from the recommendations of the WHO.These suggestions may not be included in a list ofWHO recommendations as described, as they do not specifically refer to the mechanisms of childbirth. However, the publication of the latest recommendations opens up a wide range of possibilities for the inclusion of women's desires in Birth Plans, dignifying the moment, enabling professional and peer support, ensuring informed choice, preventing abuse, and giving new meanings to childbirth.

\section{REFERENCES}

1. Organização Mundial da Saúde-OMS. Saúde Materna e Neonatal. Saúde Reprodutiva e da Família. Assistência ao parto normal: um guia prático. Genebra: Ministério da Saúde do Brasil, 1996.

2. Cortés MS, Barranco DA, Jordana MC, Martínez-Roche ME. Uso e influência dos Planos de Parto e Nascimento no processo de parto humanizado. Rev Latino-Am Enfermagem. 2015;23(3):520-6. doi: 10.1590/0104-1169.0067.2583

3. Hidalgo-Lopezosa $\mathrm{P}$, Hidalgo-Maestre M, Rodríguez-Borrego MA. O cumprimento do plano de parto e sua relação com os resultados maternos e neonatais. Rev Latino-Am. Enfermagem [Internet]. 2017 [cited 2018 Oct 06];25:e2953. Avaliable from: http://www.scielo.br/pdf/rlae/v25/ pt_0104-1169-rlae-25-e2953.pdf

4. World Health Organization. WHO recommendations: intrapartum care for a positive childbirth experience. [Internet]. 2018 [cited 2018 Oct 06]. Geneva. Avaliable from: http://apps.who.int/iris/bitstream/handle/10665/260178/9789241550215-eng.pdf?sequence=1

5. Gerenciando Blog. Site. Como aparecer no Google? [Internet]. 2016 [cited 2018 May 19]. Available from: https://www.gerenciandoblog.com. br/2011/01como-aparecer-no-google.html 
6. Cordeiro JC. Redes sociais e saúde. REDES Rev Hispana Anál Redes Soc[Internet]. 2007 [cited 2018 Mai 20];12(10). Available from: http:// www.raco.cat/index.php/Redes/article/viewFile/70399/80634

7. Organização Mundial de Saúde. OMS. Prevenção e eliminação de abusos, desrespeito e maus-tratos durante o parto em instituições de saúde. 2014 [cited 2018 May 25]. Available from: http://apps.who.int/iris/bitstream/10665/134588/3/WHO_RHR_14.23_por.pdf

8. Lüdke M, André MEDA. Pesquisa em educação: abordagens qualitativas. São Paulo: EPU; 2014.

9. História sobre os sites de busca. Site. Como ser o primeiro no Google [Internet]. s.d. [cited 2018 May 19]. Available from: https://sites.google. com/site/historiasobreossitesdebusca/otimizacao-de-sites/como-chegar-ao-topo-da-google

10. Meyer DE, Paraíso MA (Org.). Metodologias de pesquisas pós-críticas em educação. 2. ed. Belo Horizonte: Mazza Edições; 2014. 310p.

11. Ministério da Saúde (BR). Conitec. Diretriz Nacional de Assistência ao Parto Normal: relatório de recomendação. Brasília: Ministério da Saúde; 2016.

12. Lazzeri T. Vítimas da violência obstétrica: o lado invisível do parto. Época [Internet]. 2015, Aug [cited 2018 May 04]. Available from: http:// epoca.globo.com/vida/noticia/2015/08/vitimas-da-violencia-obstetrica-o-lado-invisivel-do-parto.html

13. Presidência da República (BR). Lei no 10.406. Institui o Código Civil. [Internet]. 10 de janeiro de 2002 [cited 2018 May 05]. Available from: http://www.planalto.gov.br/ccivil_03/leis/2002/L10406.htm

14. Bavaresco GZ, Souza RSO, Almeida B, Sabatino JH, Dias M. O fisioterapeuta como profissional de suporte à parturiente. Ciênc Saúde Colet. 2011;16(7):3259-66. doi: 10.1590/S1413-81232011000800025

15. Odent M. A Cientificação do amor. São Paulo:Terceira Margem; 2000. 125 p.

16. Tabarro CS, Campos LB, Galli NO, Novo NF, Pereira VN. Efeito da música no trabalho de parto e no recém-nascido. Rev Esc Enferm USP. 2010;44(2):445-52. doi: 10.1590/S0080-62342010000200029

17. Jardim DMB, Penna CMM. Pai-acompanhante e sua compreensão sobre o processo de nascimento do filho. REME - Rev Min Enferm [Internet]. 2012[cited 2018 May 04];6(3):373-38. Available from: http://www.reme.org.br/artigo/detalhes/540

18. INSTITUTO NACIONAL DE CÂNCER JOSÉ ALENCAR GOMES DA SILVA. INCA. Perguntas e Respostas sobre Sangue de Cordão Umbilical [Internet]. 2018 [cited 2018 Oct 16]. Avaliable from: http://www2.inca.gov.br/wps/wcm/connect/sobreinca/site/oinstituto/ perguntas-respostas-sobre-cordao-umbilical

19. Portal Brasil. Declaração Universal dos Direitos Humanos [Internet]. 2009. [cited 2018 May 04]. Available from: http://unesdoc.unesco.org/ images/0013/001394/139423por.pdf

20. Conselho Regional de Medicina do Estado de Pernambuco. CREMEPE. Parecer consulta n॰ 05/2013: Filmar e fotografar o parto [Internet]. 2013 [cited 2018 May 10]. Available from: http://www.radiocremepe.com.br/portal/leitorPareceres.php?cd_parecer=89

21. Prefeitura de Belo Horizonte. Assistência ao Parto e Nascimento: diretrizes para o cuidado multidisciplinar. 2015 [cited 2018 May 20 ]. Available from: protocolo-assistencia_parto_nascimento-13-01-2016.pdf

22. Leal MC, Pereira APE, Domingues RMSM, Theme-Filha MM, Dias MAB, Nakamura-Pereira M et al. Intervenções obstétricas durante o trabalho de parto e parto em mulheres brasileiras de risco habitual. Cad Saúde Pública [Internet]. 2014[cited 2018 Mai 20];30(supl.1). Available from: https://doi.org/10.1590/0102-311X00151513

23. Ministério da Saúde (BR). Secretaria de Atenção à Saúde. Departamento de Ações Programáticas e Estratégicas. Além da sobrevivência: Práticas integradas de atenção ao parto, benéficas para a nutrição e a saúde de mães e crianças. Brasília: Ministério da Saúde; 2011.

24. Ministério da Educação (BR). Hospitais Universitários. [Internet]. 2016[cited 2018 Apr 30]. Available from: http://portal.mec.gov.br/ hospitais-universitarios/hospitais-universitarios.

25. Sampaio $A R R$, Bousquat $A$, Barros $C$. Contato pele a pele ao nascer: um desafio para a promoção do aleitamento materno em maternidade pública no Nordeste brasileiro com o título de Hospital Amigo da Criança. Epidemiol Serv Saude [Internet]. 2016 [cited 2016 Jul 14];25(2):281-90. Available from: http://www.scielo.br/pdf/ress/v25n2/2237-9622-ress-25-02-00281.pdf

26. Casa Civil (BR). Estatuto da criança e do adolescente. Lei n. 8.069. 13 de julho de 1990. 14. ed. Brasília: Câmara dos Deputados/Edições Câmara; 2016. (Série legislação; n. 237).

27. Conselho Regional de Medicina do Estado de São Paulo. CREMESP. Consulta no 139.217/2012: Sobre "Plano de Parto" [Internet]. 2013 [cited 2017 Dec 15]. Available from: http://www.portalmedico.org.br/pareceres/crmsp/pareceres/2012/139217_2012.pdf

28. Ministério da Saúde (BR). Conitec. Diretrizes de Atenção à Gestante: a operação Cesariana [Internet]. 2016 [cited 2016 Mar]. Available from: http://conitec.gov.br/images/Relatorios/2016/Relatorio_Diretrizes-Cesariana_final.pdf

29. Câmara dos deputados. Prêmio Dr. Pinotti: Hospital amigo da mulher [Internet]. 2016[cited 2016 Dec 02]. Available from: http://www2. camara.leg.br/acamara/mesa/segundasecretaria/servicos/premiodrpinotti.

30. Eler GJ, Jaques AE. O enfermeiro e as terapias complementares para o alívio da dor. Arq. Ciênc. Saúde Unipar [Internet]. 2006 [cited 2018 May 20];10(3). Available from: https://www.researchgate.net/ publication/266583896_O_ENFERMEIRO_E_AS_TERAPIAS_COMPLEMENTARES_PARA_O_ALIVIO_DA_DOR 